\title{
Eksistensi Bahasa Melayu Sintang pada Media Spanduk dalam Pencegahan Penyebaran Covid-19 di Kabupaten Sintang (Kajian Etnolinguistik)
}

\author{
Yudita Susanti $^{1}$, Ursula Dwi Oktaviani ${ }^{2}$, Tedi Suryadi ${ }^{3}$ \\ STKIP Persada Khatulistiwa Sintang \\ yuditasusanti@yahoo.co.id ${ }^{1}$, ursuladwioktaviani@gmail.com ${ }^{2}$, \\ tedisuryadi.241987@gmail.com ${ }^{3}$ \\ DOI: https://doi.org/10.32528/bb.v6i1.3491
}

First received: 11-08-2020

Final proof received: 14-03-2021

\begin{abstract}
ABSTRAK
Bahasa daerah merupakan identitas, sarana dalam berkomunikasi, sebuah kearifan lokal dan hegemoni budaya suatu masyarakat sebagai penguna bahasa. Indonesia memiliki sekitar 700 bahasa daerah yang sudah didokumentasikan oleh Badan Bahasa, salah satunya bahasa Melayu Sintang. Di Kabupaten Sintang, eksisktensi bahasa Melayu Sintang digunakan dalam media spanduk dengan tujuan untuk mengajak masyarakat Kabupaten Sintang agar melakukan pencegahan terhadap penyebaran COVID-19. Eksistensi bahasa Melayu Sintang pada media spanduk dianggap mampu mempengaruhi dan mendorong pembaca sehingga mengikuti isi dari informasi yang disampaikan. Tujuan penelitian ini yaitu untuk menemukan bentuk monomorfemis dan polimorfemis dalam bahasa Melayu Sintang yang terdapat pada media spanduk dan untuk melestarikan bahasa Melayu Sintang sebagai kearifan lokal. Penelitian ini menggunakan pendekatan etnolinguistik dengan metode deskriptif kualitatif yang menjelaskan dan menguraikan bentuk monomorfemik dan polimorfemik yang terdapat dalam bahasa Melayu Sintang pada media spanduk. Teknik pengumpulan data yaitu teknik dokumentasi, teknik simak dan teknik catat. Sumber data penelitian yaitu bahasa Melayu Sintang yang terdapat dalam media spanduk. Berdasarkan hasil penelitian, pembentukan monomorfemis terdapat 24 kata yaitu pada kata bayah, pambar, aboh, utan, yak, demam, sengah, rekong, pedeh, leteh, basok, pakai, banyak, belepa, batok, tik, jom, matok, engkayuk, baik, amaki, bah, menyadik, dan sik. 24 kata tersebut merupakan morfem dasar dan tidak mengalami penambahan morfem. Pembentukan polimorfemis bentuk afiksasi sufiks (nge-) terdapat 1 kata yaitu ngetau; bentuk redupliasi terdapat 1 kata yaitu tano-tano; dan bentuk pemajemukan terdapat 6 kata yaitu bayah pambar (membentuk frasa verba), rekong pedeh (membentuk frasa adjektiva), batok sengah (membentuk frasa ajektiva), bayah am (membentuk frasa verba), nafas sesak (membentuk frasa nomina), dan jom sik (membentuk frasa nomina).

Kata kunci: Eksistensi Bahasa; Bahasa Melayu Sintang;
\end{abstract}




\begin{abstract}
Local language is an identity, a means of communication, a local wisdom and the cultural hegemony of a community as a language user. Indonesia has around 700 regional languages that have been documented by the Language Agency, one of which is Sintang Malay. In Sintang District, the existence of the Sintang Malay language is used in the banner media with the aim of inviting the people of Sintang Regency to take precautions against the spread of COVID-19. The existence of Sintang Malay language in banner media is considered capable of influencing and encouraging readers to follow the contents of the information conveyed. The purpose of this research is to find monomorphemic and polymorphemic forms in the Sintang Malay language found in the banner media and to preserve the Sintang Malay language as local wisdom. This study uses an ethnolinguistic approach with a qualitative descriptive method that explains and describes the monomorphemic and polymorphemic forms found in Sintang Malay on banner media. Data collection techniques are documentation techniques, observation techniques and note-taking techniques. The source of research data is the Sintang Malay language which is contained in the banner media. Based on the results of the study, the formation of monomorphemics contained 24 words, namely the words bayah, pambar, aboh, utan, yak, demam, sengah, rekong, pedeh, leteh, basok, pakai, banyak, belepa, batok, tik, jom, matok, engkayuk, baik, amaki, bah, menyadik, and sik. The 24 words are basic morphemes and do not experience any additional morphemes. The polymorphemic formation of the affixation suffix (nge-) contains 1 word, namely ngetau; the redupliasi form contains 1 word, namely tano-tano; and the form of compounding consists of 6 words, namely bayah pambar (forming a verb phrase), rekong pedeh (forming an adjective phrase), batok sengah (forming an adjective phrase), bayah am (forming a verb phrase), nafas sesak (forming a noun phrase), and jom sik (forming a noun phrase).

\section{Keywords: Language Existence; Sintang Malay Language; Ethnolinguistics}

\title{
1. PENDAHULUAN
}

Bahasa daerah merupakan sebuah identitas, sarana komunikasi dan kearifan lokal yang menjadi aset budaya bagi suatu kelompok masyarakat pengguna bahasa. Banyaknya jumlah bahasa daerah yang dimiliki oleh bangsa Indonesia mencerminkan keragaman budaya yang ada di Indonesia. Bahasa daerah memiliki hubungan yang erat dalam tatanan hidup masyarakat pengguna bahasa, tempat eksistensi bahasa daerah sendiri. Bahasa daerah merupakan penanda identitas suatu bangsa dan sebagai identitas utama pembentuk kakarakter normatif sebuah komunitas bangsa. Bahasa merupakan media yang dapat digunakan pengguna bahasa untuk memperoleh nilai-nilai budaya, moral, agama, nilainilai lain yang hidup di masyarakat (Taufik, Yuliana, V.Y., \& Kusnawati, 2017 ). Dengan kata lain, bahasa menjadi sarana pembelajaran nilai-nilai kehidupan bagi pengguna atau pemilik bahasa. 
Eksistensi bahasa daerah sudah dilindungi oleh Undang-Undang Dasar Tahun 1945 pasl 32 ayat 2 yang berbunyi: Negara menghormati dan memelihara bahasa daerah sebagai kekayaan budaya nasional (Republik Indonesia, Undang-Undang Dasar Tahun 1945 Pasal 32 Ayat 2, 1992). Selain itu, eksistensi bahasa daerah juga dilindungi oleh Undang-Undang Nomor 24 tahun 2009 pasal 1 yang menyatakan bahwa bahasa daerah adalah bahasa yang digunakan secara turun-temurun oleh warga negara Indonesia di wilayah Negara Indonesia (Republik Indonesia, Undang-Undang No 24 Tahun 2009 Pasal 1, 2009). Dengan memiliki perlindungan Undang-Undang yang legal dari pemerintah Indonesia, keberadaan bahasa daerah (yang ada di Indonesia) dapat diimplemetasikan sebagai salah satu cara untuk menghayati identitas dan kearifan lokal bagi masyarakat pengguna bahasa, serta memperkokoh semangat persatuan dan kesatuan bangsa Indonesia.

Penggunaan bahasa daerah oleh pengguna bahasa menjadi sarana berkomunikasi antarsesama dan sebagai identitas atau penanda dari wujud budaya masyarakat pengguna bahasa. Hal ini sejalan dengan pendapat (Sahril, 2018) yang menyatakan bahwa dalam berkomunikasi, masyarakat Indonesia banyak menggunakan bahasa daerah. Masyarakat sebagai pengguna bahasa memanfaatkan keberadaan bahasa daerah dalam berkomunikasi sehingga memunculkan interaksi, saling pengertian dan saling memahami serta menunjukkan sikap rasa hormat kepada lawan bicara (mitra tutur). Bahasa daerah menjadi identitas atau penanda asal daerah pengguna bahasa. Keberadaan bahasa daerah yang digunakan dalam berkomunikasi secara informal menjadi penunjuk langsung asal usul pengguna bahasa tersebut.

Penggunaan sebuah bahasa menjadi hal yang sangat penting dalam berkomunikasi oleh masyarakat penuturnya. Penggunaan bahasa yang digunakan harus menjadi suatu kesepakatan bahasa, bermakna dan mengacu pada suatu peristiwa, tindakan, benda dan keadaan. Peristiwa yang terjadi direalisasikan dengan bahasa sebagai perantara penuturnya. Secara umum, keberadaan bahasa memiliki empat fungsi yaitu: (1) sebagai bentuk menyatakan ekspresi diri; (2) sebagai alat berkomunikasi antarsesama; (3) sebagai alat untuk integrasi dan adaptasi sosial; dan (4) sebagai alat untuk kontrol sosial (Keraf, 2009). Dalam penelitian ini, bahasa Melayu Sintang digunakan sebagai sarana dalam menyampaikan pikiran dan gagasan yang mengiring pada sebuah tindakan atau respon terhadap maksud gagasan tersebut. Bahasa Melayu Sintang dipahami sebagai sistem perlambangan yang secara arbitrer, dibentuk atas unsur-unsur bunyi ucapan manusia dan digunakan sebagai sarana komunikasi serta dianggap mampu menyampaikan informasi yang ada pada media spanduk.

Kajian etnolinguistik pada sebuah bahasa tidak terbatas pada bahasa suku bangsa yang tidak mempunyai tulisan tetapi bahasa yang sudah mempunyai tulisan. (Crystal, 1995) menyebutkan bahwa etnolingusitik adalah cabang ilmu linguistik yang menelaah, mempelajari ragam bahasa terkait dengan keseluruhan peringkat variabel ekstra linguistik di mana terdapat basis sosial dari komunikasi yang teridentifikasi. Hal ini sejalan dengan pendapat dari (Kridalaksana H. , 2001, p. 52) yang mengatakan bahwa etnolinguistik adalah (1) salah satu cabang linguistik yang menyelidiki hubungan antara bahasa dan masyarakat yang belum memiliki tulisan bahasa, dan (2) cabang linguistik antropologi 
yang menyelidiki hubungan bahasa dan sikap pengguna bahasa terhadap bahasa. Dalam hal ini, relativitas bahasa merupakan salah satu aspek etnolingusitik yang sangat menonjol. (Kridalaksana H. , 2001, p. 187) menyebutkan relatifitas bahasa merupakan cara pandang seseorang terhadap dunia dengan bahasa yang digunakannya melalui kategori gramatikal dan klarifikasi semantik. Pada akhirnya, kategori gramatikal dan klarifikasi semantik pada suatu bahasa digunakaan secara bersamaan dalam kebudayaan. Dengan demikian, dapat disimpulkan bahwa etnolinguistik merupakan cabang ilmu bahasa yang mempelajari struktur bahasa, fungsi bahasa dan pengguna bahasa melalui sosial budaya. Dengan kata lain, etnolinguistik adalah cabang ilmu bahasa yang mempelajari asal-usul hubungan penggunaan suatu bahasa melalui masyarakat dan budaya.

Peranan bahasa sebagai alat interaksi sosial sangat besar. Hal ini dikarenakantidak ada kegiatan manusia yang berlangsung tanpa kehadiran bahasa. Kehadiran bahasa sangat dibutuhkan dakam segala kegiata, terutama dalam berkomunikasi. Bahasa merupakan alat berkomunikasi manusia yang dapat mengekspresikan apa yang menjadi pikiran dan perasaannya, baik secara lisan maupun secara tertulis. Keberhasilan komunikasi secara lisan sabgat ditentukan dengan adanya mitra tutur (penyimak), sedangkan keberhasilan komunikasi secara tertulis menggunakan media tulisan.

Eksistensi bahasa Melayu dalam kepulauan Nusantara sudah memberikan pengaruhnya sejak zaman perdagangan abad ke-15 yaitu sebagi lingua franca. Dalam kedudukannya sebagai lingua franca, Ismail Hussein dalam (Abror, 2009) mengatakan bahwa bahasa Melayu merupakan bahasa yang paling luas dan beragam cara pengucapannya atau bersifat kosmopolitan, baik di nusantara maupun Asia Tenggara. Kedudukan bahasa Melayu sebagai lingua franca merupakan sebuah pencapaian yang sangat gemilang, di mana pada abad perdagangan, bahasa Melayu merupakan bahasa yang harus dikuasai oleh pedagang yang tidak hanya berasal dari nusantara tetapi dari negara Eropa.

Penggunaan bahasa Melayu Sintang pada media spanduk Dinas Kesehatan Kabupaten Sintang dalam pencegahan penyebaran COVID-19 memandakan bahwa eksistensi bahasa daerah masih terjaga. Hal ini dilakukan untuk memberikan informasi yang mudah dipahami dan memudahkan para pembaca dalam mencegah penyebaran COVID-19. Bahasa iklan yang digunakan dalam media spanduk tersebut dianggap menarik minat pembaca. Bahasa iklan adalah bahasa yang digunakan untuk membuat iklan. (Kasali, 1995, p. 9) mengatakan iklan adalah berita pesanan untuk membujuk, medorong khalayak ramai agar tertarik pada barang atau jasa dengan bahasa yang menarik. Bahasa yang dimaksud adalah bahasa yang dianggap menarik orang (khalayak ramai) untuk membeli atau menggunakan jasa atau barang yang ditawarkan. Dalam hal ini, bahasa iklan yang akan dianalisis bukan bahasa iklan menjual barang dan jasa melainkan bahasa iklan layanan kesehatan dalam mencegah penyebaran COVID-19 yang menggunakan bahasa Melayu Sintang.

Keunikan bahasa iklan yang menggunakan bahasa daerah menjadi ciri khas yang mampu mendorong para masyarakat untuk melakukan hal seperti yang tertulis dalam iklan spanduk. Ciri khas lainnya yaitu ditunjukkan melalui gaya tuturan, pilihan kata atau 
diksi yang tepat untuk menyampaikan pesan yang ingin disampaikan sehingga iklan tersebut mencapai sasaran. Informasi pada iklan dapat diterima dan ditanggapi dengan baik oleh masyarakat apabila disajikan dengan persuasif dan komunikatif. Hal inilah yang menjadi faktor penyebab sebagian orang akan menjadi simpati setelah membaca iklan dalam bentuk media massa cetak seperti spanduk. Spanduk adalah kain rentang yang berisi slogan, propaganda, atau berita yang perlu diketahui umum (KBBI). Spanduk merupakan sebuah wacana persuasif yang dapat mempengaruhi pembaca. Komunikasi persuasif dapat terjadi apabila pesan spanduk dibuat semenarik mungkin dengan bahasa yang tepat, sesuai, mudah dipahami, diksi yang tepat dan gaya tuturan yang mencerminkan kearifan lokal.

Penggunaan bahasa Melayu pada iklan spanduk Dinas Kesehatan Kabupaten Sintang dalam pencegahan penyebaran COVID-19 di Kabupaten Sintang menggunakan bahasa yang tepat, sesuai dengan pengguna bahasa, gaya tuturan yang mencerminkan kearifan lokal menjadi alternatif solusi pencegahan penyebaran COVID-19 di masyarakat. Dinas Kesehatan Kabupaten Sintang memilih menggunakan bahasa Melayu pada spanduk pencegahan penyebaran COVID-19 supaya informasi tepat sasaran dan mudah dipahami dalam mensosialisasikan program tersebut kepada masyarakat yang tidak memahami bahasa Indonesia dengan baik.

Penelitian ini akan menganalisis penekanan bentuk kata pada bahasa Melayu Sintang yang digunakan dalam media spanduk. Penekanan bentuk kata yang dimaksud yaitu pembentukan monomorfemis dan polimorfemis. Monomorfemis adalah kata-kata yang terdiri dari satu morfem. Morfem merupakan satuan terkecil yang maknanya relatif stabil dan tidak dapat dibagi atas bagian makna yang lebih kecil (Kridalaksana H. , 2001, p. 148). Contoh bentuk morfem rumah, batu, buku, ibu, doa dan sepatu. Polimorfemis merupakan bentuk kata yang kompleks, terdiri dari satuan yang lebih kecil, terbentuk karena adanya morfologis, melalu afiksasi, reduplikasi atau pemajemukan. Dengan kata lain, polimorfemis adalah kata yang terdiri lebih dari satu morfem.

\section{METODE}

Metode penelitian merupakan salah satu cara yang dapat digunakan oleh peneliti dalam mengamati, menganalisis dan menjelaskan fenomena yang sedang diteliti. Pendekatan yang digunakan dalam penelitian ini yaitu pendekatan etnolinguistik. Metode pengumpulan data dalam penelitian ini yaitu metode deskriptif kualitatif, menjelaskan dan mendeskripsikan bentuk monomorfemik dan polimorfemik pada media spanduk. Teknik pengumpulan data dalam penelitian ini yaitu teknik dokumentasi, teknik simak dan teknik catat. Dokumentasi merupakan catatan peristiwa yang sudah berlalu, dokumen yang berbentuk gambar misalnya foto, gambar hidup, sketsa dan lain-lain (Sugiyono, 2012, p. 240). Pada penelitian ini, metode dokumentasi dilakukan dengan cara mengambil gambar spanduk Dinas Kesehatan Kabupaten Sintang dalam pencegahan penyebaran COVID-19 yang terdapat di Kabupaten Sintang menggunakan kamera digital. Teknik simak merupakan cara yang digunakan peneliti untuk memperoleh data yaitu dengan cara menyimak penggunaan bahasa (Mahsun, 2007, p. 29). Teknik simak digunakan untuk mendapatkan data berupa terjemahan dari bahasa Melayu Sintang ke dalam bahasa 
Indonesia. Data diperoleh dari pengguna bahasa Melayu Sintang sesuai dengan bahasa yang terdapat pada spanduk. Teknik catat merupakan teknik lanjutan yang dilakukan ketika sudah menerapkan teknik simak (Sudaryanto, 1993, p. 133). Teknik simak yaitu mencatat data yang diperoleh. Dalam teknik ini, data yang dicatat berupa kata dan kalimat yang berkaitan dengan penelitian dalam bentuk monomorfemis dan polimorfemis. Data penelitian ini yaitu bahasa Melayu Sintang yang terdapat dalam media spanduk.

\section{PEMBAHASAN}

Kedudukan bahasa Melayu di Kabupaten Sintang merupakan identitas pengguna bahasanya. Suku Melayu merupakan kelompok masyarakat yang besar di Kabupaten Sintang, khususnya di kota Sintang. Pembentukan identitas suku Melayu di Kabupaten Sintang dimulai sejak agama Islam masuk ke wilayah Kabupaten Sintang. Sebutan Melayu digunakan untuk menyebut identitas penduduk di Kabupaten Sintang yang beragama Islam.

Kabupaten Sintang merupakan salah satu kabupaten yang mengunakan media spanduk dalam menghimbau pencegahan penyebaran virus corona atau COVID-19. Penggunaan bahasa Melayu dalam media spanduk merupakan bentuk eksistensi bahasa Melayu di Kabupaten Sintang. Bahasa dianggap mampu mengajak para pembaca untuk mengikuti atau melaksanakan hal yang terkandung dalam media spanduk. Penyebaran virus corona yang semakin meluas dan meningkat menjadi perhatian khusus bagi pemerinta setempat. Karena alasan inilah pemerintah di beberapa negara, termasuk Indonesia, menghimbau kepada masyarakat agar dapat memutuskan penyebaran virus corona. Salah satu cara yang dihimbau kepada masyarakat yaitu menerapkan kebiasaan hidup sehat. Dengan menerapkan kebiasaan hidup sehat maka masyarakat Indonesa dapat menghentikan atau memutus rantai penyebaran virus corona. Dalam penghimbauan hal tersebut, Indonesia (khususnya wiayah Kabupaten Sintang) memlilih media spanduk. Hal ini bertujuan agar informasi yang ingin disampaikan tepat sasaran dan lebih mudah disosialisasikan kepada masyarakat.

Media spanduk dianggap sebagai media luar ruang yang memudahkan menyampaikan informasi kepada pembaca. Menurut (Badan Pengembangan dan Pembinaan Bahasa, 2016, p. 9), media luar ruang adalah sarana komunikasi yang menggunakan alat tertentu yang diletakkan di luar ruang atau di luar gedung. Media luar ruang merupakan satu di antara media yang ada yang digunakan sebagai sarana komunikasi untuk menyampaikan suatu informasi. Dengan adanya media luar ruang, seseorang akan mendapatkan informasi dengan mudah. Dalam mempermudah penyampaian informasi tentang pencegahan penyebaran virus corona, pemerintah kabupaten Sintang memilih media luar ruang sebagai sarana komunikasi. Media luar ruang yang digunakan yaitu media spanduk. Bahasa yang digunakan dalam media spanduk menggunakan bahasa daerah, yaitu bahasa Melayu Sintang. Eksistensi bahasa Melayu Sintang pada media spanduk dapat mempermudah masyarakat cepat mengerti sehingga masyarakat cepat sadar menjalankan aturan dan pandemi segera berakhir.

Deskripsi secara umum, objek media spanduk yang diteliti berjumlah 2 data yang terdiri dari 1 data dari Jalan Lintas Melawi, dan 1 data dari Jalan Pembangunan. 
Berdasarkan 2 data yang ditemukan, terdapat 110 kata yang akan dianalisis, baik secara monomorfemis dan polimorfemik. Monomorfemis adalah bentuk dasar atau yang terdiri dari satu morfem dan tidak dapat dibagi atas bagian makna yang lebih kecil sedangkan polimorfemis merupakan bentuk kata yang kompleks, terdiri dari satuan yang lebih kecil. Dengan kata lain, polimorfemis adalah kata yang terdiri lebih dari satu morfem. Polimorfemis terjadi karena hasil proses morfologis seperti afiksasi, reduplikasi dan pemajemukan. Dengan kata lain, monomorfemis bentuk tunggal, sedangkan polimorfemis bentuk turunan.

\section{a) Monomorfemis}

Monomorfemis merupakan kata dasar, tanpa berimbuhan, terbentuk dari satu morfem. (Ramlan, 2001, p. 183) mengatakan bahwa monomorfemis terjadi karena adanya peristiwa fonologi yang terjadi. Monomorfemis adalah kata yang terdiri dari satu morfem, satuan gramatik terkecil yang tidak dapat dibagi lagi atas satuan lingual bermakna yang lebih kecil (Kridalaksana H. , 1993, p. 148). Monomorfemis tergolong kata dasar, bentuk tunggal, morfem yang dapat berdiri sendiri. Dengan kata lain, monomorfemis tidak mengalami morfologis atau atau belum mendapat tambahan morfem lain. Artinya, kata dasar tersebut tidak mengalami afiksasi (pengimbuhan), redupliaksi (pengulangan) dan pemajemukan. Bentuk monomorfemis bahasa Melayu Sintang pada media spanduk Dinas Kesehatan Kabupaten Sintang dalam pencegahan penyebaran COVID-19 di Kabupaten Sintang sebagai berikut.

\begin{tabular}{c|c|l}
$\begin{array}{c}\text { Bentuk } \\
\text { Monomorfemis } \\
\text { Bahasa Melayu Sintang }\end{array}$ & Kode & \multicolumn{1}{|c}{ Arti dalam Bahasa Indonesia } \\
\hline Bayah & $\mathrm{K} 3$ & Jangan, melarang, tidak boleh melakukan \\
\hline Pambar 3 & $\begin{array}{l}\text { Panik, khawatir terlalu berlebihan, bingung, } \\
\text { gugup, atau takut dengan mendadak sehingga } \\
\text { tidak dapat berpikir dengan tenang }\end{array}$ \\
\hline Aboh & $\mathrm{K} 4$ & Ayo, mari \\
\hline Utan & $\mathrm{K} 4$ & Sesuatu \\
\hline Kemam 4 & $\begin{array}{l}\text { Tersebut, sudah disebutkan, sudah dikatakan } \\
\text { sebelumnya }\end{array}$ \\
\hline Sengah & $\mathrm{K} 5^{2}$ & $\begin{array}{l}\text { Demam, rasa sakit yang ditandai dengan suhu } \\
\text { badan menjadi lebih tinggi dan merasa pusing }\end{array}$ \\
\hline Rekong & $\begin{array}{l}\text { Flu, penyakit menular pada saluran pernapasan } \\
\text { yang disebabkan oleh virus; influenza; pilek }\end{array}$ \\
\hline Pedeh $5^{4}$ & $\begin{array}{l}\text { Tenggorokan, bagian saluran napas atas antara } \\
\text { laring dan percabangan bronkus }\end{array}$ \\
\hline Leteh & $\mathrm{K} 5^{4}$ & $\begin{array}{l}\text { Sakit, berasa tidak nyaman di tubuh atau bagian } \\
\text { tubuh karena menderita sesuatu }\end{array}$ \\
\hline Basok & $\mathrm{K} 5^{5}$ & Letih, tidak bertenaga, lelah sekali \\
\hline Pakai & $\mathrm{K} 6^{1}$ & Cuci, membersihkan sesuatu dengan air \\
\hline Banyak $66^{1}$ & $\begin{array}{l}\text { Menggunakan 'memakai; menggunakan dengan } \\
\text { sesuatu' }\end{array}$ \\
\hline belepa & $\mathrm{K} 6^{2}$ & Sering, kerap, acap \\
\hline Istirahat, berhenti sebentar dari suatu kegiatan \\
\hline
\end{tabular}




\begin{tabular}{c|c|l}
\hline Batok & $\mathrm{K} 6^{3}$ & $\begin{array}{l}\text { Batuk, rasa gatal yang sangat kuat pada bagian } \\
\text { tenggorokan akibat penyumbatan jalan } \\
\text { pernapasan sehingga penderita mengeluarkan } \\
\text { bunyi yang keras melalui mulut }\end{array}$ \\
\hline Tik & $\mathrm{K} 6^{3}$ & $\begin{array}{l}\text { Jika, kata penghubung untuk menandai syarat } \\
\text { (janji), kalau }\end{array}$ \\
\hline Jom & $\mathrm{K} 6^{3}$ & $\begin{array}{l}\text { Tidak, partikel untuk menyatakan pengingkaran, } \\
\text { penolakan, penyangkalan, dan sebagainya; tiada }\end{array}$ \\
\hline Motok & $\mathrm{K} 6^{4}$ & Mentah, belum masak; belum matang \\
\hline Engkayuk & $\mathrm{K} 6^{5}$ & Sayur daun-daunan \\
\hline Baik & $\mathrm{K} 6^{6}$ & Bawa, angkat ke tempat lain \\
\hline Makai & $\mathrm{K} 7$ & \begin{tabular}{l} 
gunakan \\
\hline Bah
\end{tabular} \\
\hline $\mathrm{K} 7$ & $\begin{array}{l}\text { Ya, kata untuk memberi tekanan pada suatu } \\
\text { pernyataan }\end{array}$ \\
\hline Menyadik & $\mathrm{K} 7$ & $\begin{array}{l}\text { Saudara, sapaan kepada orang yang diajak } \\
\text { berbicara }\end{array}$ \\
\hline Sik & & Ada, mempunyai \\
\hline
\end{tabular}

Monomorfemis adalah kata yang terdiri dari satu morfem, satuan gramatik terkecil yang tidak dapat dibagi lagi atas satuan lingual bermakna yang lebih kecil dan tergolong kata dasar. Monomorfems berbentuk tunggal, morfem yang dapat berdiri sendiri, tidak mengalami morfologis atau belum mendapat tambahan morfem lain. Artinya, kata dasar tersebut tidak mengalami afiksasi (pengimbuhan), redupliaksi (pengulangan) dan pemajemukan.

Monomorfemis bahasa Melayu Sintang pada media spanduk dalam pencegahan penyebaran COVID-19 di Kabupaten Sintang sebagai berikut.

$\begin{array}{ll}\text { bayah } & \text { jangan } \\ \text { pambar } & \text { panik } \\ \text { aboh } & \text { ayo } \\ \text { utan } & \text { sesuatu } \\ \text { yak } & \text { tersebut } \\ \text { demam } & \text { demam } \\ \text { sengah } & \text { flu } \\ \text { rekong } & \text { tenggorokan } \\ \text { pedeh } & \text { sakit } \\ \text { leteh } & \text { letih } \\ \text { basok } & \text { cuci } \\ \text { pakai } & \text { menggunakan } \\ \text { banyak } & \text { sering } \\ \text { belepa } & \text { istirahat } \\ \text { batok } & \text { batuk } \\ \text { tik } & \text { jika } \\ \text { jom } & \text { tidak } \\ \text { matok } & \text { mentah } \\ \text { engkayuk } & \text { sayur }\end{array}$




$\begin{array}{ll}\text { baik } & \text { bawa } \\ \text { makai } & \text { gunakan } \\ \text { bah } & \text { ya } \\ \text { menyadik } & \text { saudara } \\ \text { sik } & \text { ada }\end{array}$

Berdasarkan data di atas, kata-kata tergolong ke dalam monomorfemis karena tergolong ke dalam morfem dasar dan tidak mengalami penambahan morfem. Dapat disimpulkan bahwa Bahasa Melayu Sintang yang digunakan pada media spanduk Dinas Kesehatan Kabupaten Sintang dalam pencegahan penyebaran COVID-19 di Kabupaten Sintang terdapat 24 morfem dasar.

\section{b) Polimorfemis}

Polimorfemis yaitu kata yang merupakan bentuk kompleks atau terdiri dari satuan yang lebih kecil, terdiri lebih dari satu morfem. Polimorfemis merupakan hasil dari proses morfologis. Bentuk-bentuk polimorfemis meliputi : (1) afiksasi atau pengimbuhan. (2) reduplikasi atau pengulangan, dan (3) pemajemukan. Adapun kata-kata yang termasuk dalam bentuk polimorfemis pada bahasa Melayu Sintang pada media spanduk Dinas Kesehatan Kabupaten Sintang dalam pencegahan penyebaran COVID-19 di Kabupaten Sintang sebagai berikut.

\begin{tabular}{|c|c|c|c|}
\hline $\begin{array}{c}\text { Bentuk } \\
\text { Polimorfemis } \\
\text { Bahasa } \\
\text { Melayu } \\
\text { Sintang } \\
\end{array}$ & Kode & $\begin{array}{c}\text { Proses } \\
\text { Polimorfemis }\end{array}$ & $\begin{array}{l}\text { Arti dalam Bahasa } \\
\text { Indonesia }\end{array}$ \\
\hline Bayah pambar & $\mathrm{K} 3$ & $\begin{array}{l}\text { Pemajemukan } \\
\text { Frasa endosentris } \\
\text { Bayah+pambar } \\
\text { pambar }\end{array}$ & $\begin{array}{l}\text { Jangan panik 'tidak } \\
\text { perlu khawatir/panik } \\
\text { terlalu berlebihan' }\end{array}$ \\
\hline Ngetau & K4 & $\begin{array}{l}\text { Afiksasi } \\
\text { Prefiks (nge-) } \\
\text { nge-+tau }\end{array}$ & $\begin{array}{l}\text { Mengenal, tahu, } \\
\text { paham, mengerti } \\
\text { 'mengetahui; } \\
\text { mempunyai rasa ingin } \\
\text { tahu' }\end{array}$ \\
\hline Tano-tano & $\mathrm{K} 4$ & $\begin{array}{l}\text { Ruduplikasi } \\
\text { Pengulangan bunyi } \\
\text { tano-tano } \\
\text { tano }\end{array}$ & $\begin{array}{l}\text { Tanda-tanda } \\
\text { 'petunjuk, ciri-ciri' }\end{array}$ \\
\hline Rekong pedeh & $K 5^{4}$ & $\begin{array}{l}\text { Pemajemukan } \\
\text { Frasa endosentris } \\
\text { rekong+pedeh } \\
\text { pedeh }\end{array}$ & $\begin{array}{l}\text { Sakit tenggorokan } \\
\text { 'tenggorokan dalam } \\
\text { keadaan sakit karena } \\
\text { batuk' }\end{array}$ \\
\hline Batok sengah & $K 6^{3}$ & $\begin{array}{l}\text { Pemajemukan } \\
\text { Frasa endosentris }\end{array}$ & $\begin{array}{l}\text { Batuk pilek 'keadaan } \\
\text { sakit pernafasan dan }\end{array}$ \\
\hline
\end{tabular}




\begin{tabular}{|c|c|c|c|c|}
\hline & & $\begin{array}{l}\text { batok+sengah } \\
\text { sengah }\end{array}$ & batok & $\begin{array}{l}\text { tenggorokan karena } \\
\text { virus' }\end{array}$ \\
\hline Bayah am & $\mathrm{K} 6^{3}$ & $\begin{array}{l}\text { Pemajemukan } \\
\text { Frase endosentris } \\
\text { bayah+am } \\
\text { am }\end{array}$ & bayah & $\begin{array}{l}\text { Jangan digunakan } \\
\text { 'tidak boleh dipakai; } \\
\text { melarang' }\end{array}$ \\
\hline Nafas sesak & $K 6^{6}$ & $\begin{array}{l}\text { Pemajemukan } \\
\text { Fease endosentris } \\
\text { nafas }+ \text { sesak } \\
\text { sesak }\end{array}$ & nafas & $\begin{array}{l}\text { Sesak nafas 'susah } \\
\text { atau sukar bernafas' }\end{array}$ \\
\hline Jom sik & & $\begin{array}{l}\text { Pemajemukan } \\
\text { Fease endosentris } \\
\text { jom }+ \text { sik } \\
\text { sik }\end{array}$ & jom & $\begin{array}{l}\text { Tidak ada 'belum } \\
\text { mempunyai' }\end{array}$ \\
\hline
\end{tabular}

Polimorfemis merupakan bentuk turunan pada sebuah morfem dan mengalami morfologis sehingga terdiri lebih dari satu morfem. Polimorfemis merupakan hasil dari proses morfologis. Bentuk-bentuk polimorfemis meliputi: (1) afiksasi atau pengimbuhan. (2) reduplikasi atau pengulangan, dan (3) pemajemukan. Polimorfemis bahasa Melayu Sintang pada media spanduk dalam pencegahan penyebaran COVID-19 di Kabupaten Sintang sebagai berikut.

\section{(1) Afiksasi}

Afiksasi adalah proses pembubuhan atau penggabungan afiks pada sebuah kata dasar. Afiksasi adalah salah satu proses dalam pembentukan kata turunan baik berkategori verba, nomina, maupun adjektiva (Chaer, 2008, p. 106). Afiks dapat membentuk dan menunjukkan makna kategorial bentuk dasar. Afiksasi berdasarkan posisinya ada yang berupa prefiks (awalan), infiks (sisipan), sufiks (akhiran), dan simulfiks (konfiks). Afiksasi yang ditemukan pada bahasa Melayu Sintang pada media spanduk yaitu pada kata ngetau.

Prefiks (nge-) membentuk kata kerja
a. nge- + tau
prefiks $\quad \mathrm{MB}$
$\longrightarrow \quad$ ngetau
KT
mengenal
KT

Kata ngetau tergolong prefiks (awalan) karena kata ngetau mengalami imbuhan nge-, sedangkan kata tau merupakan kata dasar atau morfem bebas (MB) yang dapat berdiri sendiri. Kata tau memiliki makna tahu, paham, mengerti, sedangkan prefiks nge- merupakan proses morfologi. Kata tau akan mengalami perubahan makna dan perubahan bentuk dari kata tunggal menjadi kata turunan. Kata tau digabung dengan prefiks nge- menjadi ngetau. Kata ngetau memiliki makna mengenal, memahami, mengerti atau 
mengetahui dan masuk pada kata turunan (KT). Prefiks nge- membentuk kata kerja.

\section{(2) Reduplikasi}

Reduplikasi adalah proses morfemis yang mengulang bentuk dasar, baik secara keseluruhan, parsial (sebagian), maupun perubahan bunyi. Menurut (Chaer, 2008, p. 178), reduplikasi adalah pengulangan bentuk satuan kebahasaan yang terdapat di salam bahasa. Reduplikasi dapat terjadi pada bentuk dasar yang berupa akar, merupakan bentuk berafiks dan berupa bentuk komposisi. Hasil pengulangan disebut reduplikasi sedangkan satuan yang diulang merupakan kata dasar. Reduplikasi yang ditemukan pada bahasa Melayu Sintang pada media spanduk terdapat pada kata tano-tano.
a. tano
tano

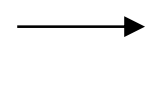
tano-tano tanda-tanda
$\mathrm{MB}$
$\mathrm{MB}$
Reduplikasi

Kata ulang (redupliaksi) dari bentuk dasar monomorfemis kata tano mengalami perubahan bentuk turunan kata menjadi kata ulang tano-tano. Kata tano merupakan morfem bebas dan mengalami reduplikasi menjadi tano-tano. Reduplikasi tano-tano merupakan bentuk pengulangan secara utuh karena mengalami pengulangan kata secara keseluruhan. Kata ulang tano-tano memiliki makna tanda-tanda, petunjuk, atau ciri-ciri. Bentuk dasar kata tano menerangkan kata benda.

\section{(3) Pemajemukan}

Pemajemukan merupakan penjejeran dua kata atau lebih itu menumbuhkan makna yang secara langsung masih bisa ditelusuri dari makna masing-masing kata yang tergabung (Alwi, Lapoliwa, \& Darmowidjojo, 2003, p. 151).Pemajemukan adalah proses pembentukan kata melalui penggabungan dua kata yang menimbulkan suatu kata baru dan memberikan pengertian baru yang khusus. Pengabungan kata tersebut dapat berupa akar + akar, pokok + pokok, pokok + akar, atau akar + pokok. Pemajemukan yang ditemukan pada bahasa melayu Sintang pada media spanduk terdapat pada kata bayah pambar, rekong pedeh, batok sengah, bayah am, nafas sesak, dan jom si.
a. bayah
$+\quad$ pambar
$\mathrm{MB}$
b. rekong
$\mathrm{MB}$
$\mathrm{MB}$
$+\quad$ pedeh
c. batok
MB
$\mathrm{MB}$
$+$
sengah
$\mathrm{MB}$
d. bayah
$+\quad a m$
MB
MB

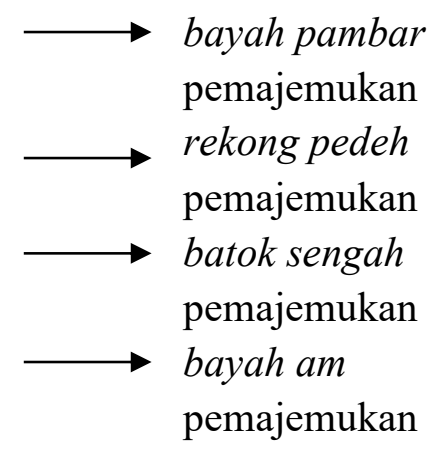




\begin{tabular}{|c|c|c|c|}
\hline $\begin{array}{ll}\text { e. } & \text { nafas } \\
& \mathrm{MB}\end{array}$ & + & $\begin{array}{l}\text { sesak } \\
\mathrm{MB}\end{array}$ & $\begin{array}{l}\text { nafas sesak } \\
\text { pemajemukan }\end{array}$ \\
\hline $\begin{array}{r}\text { f. } \\
\text { jom }\end{array}$ & + & $\begin{array}{l}\text { sik } \\
\quad \mathrm{MB}\end{array}$ & $\begin{array}{l}\text { jom sik } \\
\text { pemajemukan }\end{array}$ \\
\hline
\end{tabular}

Kata bayah pambar merupakan morfem bebas yang terdiri dari kata bayah dan pambar, mengalami pemajemukan (penggabungan morfem) menjadi bayah pambar. Kata bayah pambar membentuk frasa verba dan mengalami pemajemukan frasa endosentris karena memiliki distribusi yang sama pada kata bayah dan pambar. Makna kata bayah pambar yaitu jangan panik.

Kata rekong pedeh merupakan morfem bebas yang terdiri dari kata rekong dan pedeh, mengalami pemajemukan menjadi rekong pedeh. Kata rekong pedeh membentuk frasa adjektiva dan mengalami pemajemukan frasa endosentris karena memliki distribusi yang sama pada kata rekong dan pedeh. Makna kata rekong pedeh yaitu sakit tenggorokan.

Kata batok sengah merupakan morfem bebas yang terdiri dari kata batok dan sengah, mengalami pemajemukan menjadi batok sengah. Kata batok sengah membentuk frasa adjektiva dan mengalami pemajemukan frasa endosentris karena memiliki distribusi yang sama pada kata batok dan sengah. Makna kata batok sengah yaitu batuk pilek.

Kata bayah am meupakan morfem bebas yang terdiri dari kata bayah dan am, mengalami pemajemukan menjadi bayah am. Kata bayah am membentuk frasa verba dan mengalami pemajemukan frasa endosentris karena memiliki distribusi yang sama pada kata bayah dan am. Makna kata bayah am yaitu jangan digunakan.

Kata nafas sesak merupakan morfem bebas yang terdri dari kata nafas dan sesak, mengalami pemajemukan menjadi nafas sesak. Kata nafas sesak membentuk frasa nomina dan mengalami pemajemukan frasa endosenstris karena memiliki distribusi yang sama pada kata nafas dan sesak. Makna kata nafas sesak yaitu sesak nafas.

Kata jom sik merupakan morfem bebas yang terdiri dari kata jom dan sik, mengalami pemajemukan menjadi jom sik. Kata jom sik membentuk frasa nomina dan mengalami pemajemukan frasa endosentris karena memilk distribus yang sama pada kata jom dan sik. Makna kata jom sik yaitu tidak ada.

Berdasarkan analisis data di atas, terdapat 8 morfem pada komposisi polimorfemik. Bentuk polimorfemis afiksasi ada 1 yaitu kata ngetau; bentuk polimorfemik reduplikasi ada 1 yaitu kata tano-tano; bentuk polimorfemis pemajemukan ada 6 , yaitu kata bayah pambar, rekong pedeh, batok sengah, bayah am, nafas sesak, jom sik. Kata bayah pambar, rekong pedeh, batok sengah, bayah am, nafas sesak, jom sik tergolong ke dalam polimorefmis pemajemukan frasa endosentris.

\section{SIMPULAN}


Berdasarkan hasil analisis di atas, bahasa Melayu Sintang yang terdapat pada media spanduk Dinas Kesehatan Kabupaten Sintang dalam pencegahan penyebaran COVID-19 di Kabupaten Sintang memiliki dua pembentukan kata yaitu bentuk monomorfemis dan polimorfemis. Kesimpulan yang dapat dirumuskan berdasarkan analisis penelitian sebagai berikut.

a) Monomorfemis

Monomorfemis mencakup semua kata yang tergolong kata dasar dan berbentuk tunggal dan tidak mengalami penambahan morfem. Monomorfemis yang terdapat dalam bahasa Melayu Sintang pada media spanduk ada 24 morfem yaitu bayah, pambar, aboh, utan, yak, demam, sengah, rekong, pedeh, leteh, basok, pakai, banyak, belepa, batok, tik, jom, matok, engkayuk, baik, amaki, bah, menyadik, dan sik.

b) Polimorfemis

Bentuk polimorfemis dalam bahasa Melayu Sintang pada media spanduk meliputi: afiksasi atau pengimbuhan, reduplikasi atau pengulangan, dan pemajemukan. Bahasa Melayu Sintang yang mengalami bentuk polimorfemis secara afiksasi prefiks (nge-) adalah ngetau dan membentuk kata kerja.

Bentuk polimorfemis reduplikasi (pengulangan) adalah kata tano-tano; mengalami pengulangan secara utuh karena mengalami pengulangan kata secara keseluruhan. Kata ulang tano-tano memiliki makna tanda-tanda, petunjuk, atau ciri-ciri. Bentuk dasar kata tano menerangkan kata benda.

Bentuk pemajemukan terdapat pada kata bayah pambar, rekong pedeh, batok sengah, bayah am, nafas sesak, jom sik. (1) kata bayah pambar merupakan morfem bebas yang terdiri dari kata bayah dan pambar, mengalami pemajemukan (penggabungan morfem) menjadi bayah pambar. Kata bayah pambar membentuk frasa verba dan mengalami pemajemukan frasa endosentris karena memiliki distribusi yang sama pada kata bayah dan pambar. Makna kata bayah pambar yaitu jangan panik; (2) kata rekong pedeh merupakan morfem bebas yang terdiri dari kata rekong dan pedeh, mengalami pemajemukan menjadi rekong pedeh. Kata rekong pedeh membentuk frasa adjektiva dan mengalami pemajemukan frasa endosentris karena memliki distribusi yang sama pada kata rekong dan pedeh. Makna kata rekong pedeh yaitu sakit tenggorokan; (3) kata batok sengah merupakan morfem bebas yang terdiri dari kata batok dan sengah, mengalami pemajemukan menjadi batok sengah. Kata batok sengah membentuk frasa adjektiva dan mengalami pemajemukan frasa endosentris karena memiliki distribusi yang sama pada kata batok dan sengah. Makna kata batok sengah yaitu batuk pilek; (4) kata bayah am meupakan morfem bebas yang terdiri dari kata bayah dan am, mengalami pemajemukan menjadi bayah am. Kata bayah am membentuk frasa verba dan mengalami pemajemukan frasa endosentris karena memiliki distribusi yang sama pada kata bayah dan am. Kata kata bayah am yaitu jangan digunakan; (5) kata nafas sesak merupakan morfem bebas yang terdri dari kata nafas dan sesak, mengalami pemajemukan menjadi nafas sesak. Kata nafas sesak membentuk frasa nomina dan mengalami pemajemukan frasa endosenstris karena memiliki distribusi yang sama pada kata nafas dan sesak. Makna kata nafas sesak yaitu sesak nafas; (6) kata jom sik merupakan morfem bebas yang terdiri dari kata jom dan sik, mengalami pemajemukan 
menjadi jom sik. Kata jom sik membentuk frasa nomina dan mengalami pemajemukan frasa endosentris karena memilk distribusi yang sama pada kata jom dan sik. Makna kata jom sik yaitu tidak ada.

\section{DAFTAR RUJUKAN}

Abror, A. (2009). Pantun Melayu, Titik Temu Islam dan Budaya Lokal Nusantara. Yogyakarta: Lkis.

Alwi, H., Lapoliwa, H., \& Darmowidjojo, S. (2003). Tata Bahasa Baku Bahasa Indonesia. Jakarta: Balai Pustaka.

Badan Pengembangan dan Pembinaan Bahasa. (2016). Pedoman Pemantauan Bahasa di Media Luar Ruang. Jakarta: Kementrian Pendidikan dan Kebudayaan.

Chaer, A. (2008). Gramatikal Bahasa Indonesia. Jakarta: Rineka Cipta.

Crystal, D. (1995). The Cambridge Encyclopedia of The English Language. Cambridge: Cambridge University Press.

Kasali, R. (1995). Manajemen Periklanan Konsep dan Aplikasinya di Indonesia. Jakarta: Pustaka Utama Grafity.

Keraf, G. (2009). Diksi dan Gaya Bahasa. Jakarta: Gramedia Pustaka.

Kridalaksana, H. (1993). Kamus Linguistik. Jakarta: Gramedia Pustaka.

Kridalaksana, H. (2001). Kamus Linguistik. Jakarta: Gramedia Pustaka Utama.

Mahsun. (2007). Metode Penelitian Bahasa. Jakarta: PT Raja Grafindo Persada.

Ramlan. (2001). Morfologi Suatu Tinjauan Deskriptif. Yogyakarta: CV Karyono.

Republik Indonesia. (1992). Undang-Undang Dasar Tahun 1945 Pasal 32 Ayat 2. Jakarta: Sekretariat Negara.

Republik Indonesia. (2009). Undang-Undang No 24 Tahun 2009 Pasal 1. Jakarta: Sekretariat Negara.

Sahril, N. (2018). Pergeseran Bahasa Daerah Pada Anak-Anak di Kuala Tanjung Sumatra Utara. Ranah: Jurnal Kajian Bahasa, 210-228, Vol.7, No.2.

Sudaryanto. (1993). Metode dan Aneka Teknik Analisis Bahasa (Pengantar Penelitian Wahana Kebudayaan Secara Linguistik). Yogyakarta: Duta Wacana University Press.

Sugiyono. (2012). Metode Penelitian Kualitatif, Kuantitatif dan R\&D. Bandung: Alfabeta. 
Taufik, M., Yuliana, R., V.Y., I. A., \& Kusnawati, M. (2017 ). BAHASA DAERAH SEBAGAI MOTHER LANGUAGE DALAM UPAYA PENGUATAN KEARIFAN LOKAL IDENTITAS BANTEN DI KOTA SERANG. Jurnal Membaca Bahasa dan Sastra Indonesia, Vol. 2, No.159-68. 
